\title{
Methods for developing the creative potential of future teacher-linguists in their studies
}

\author{
Galina V. Sorokoumova ${ }^{1^{*}}$ \\ ${ }^{1}$ Linguistics University of Nizhny Novgorod, Department of Methods of Teaching Foreign \\ Languages, Pedagogics and Psychology, Nizhny Novgorod, Russia
}

\begin{abstract}
The paper reveals the need to solve the problem of improving the quality of training of a future teacher at a university in the context of state requirements for the modernization of national education. The object of consideration in the paper is the quality of preparation of a future teacher of a foreign language at a university, the subject is the development of the creative potential of the teacher's personality through the use of active methods, among which creativity training is of primary importance. The content of the paper is based on the analysis and generalization of scientific publications that reveal the issues of the quality of education, requirements for the professional personality and activities of the teacher, characterizing active teaching methods in teacher training. To diagnose the creative potential of students willing to become teachers of a foreign language, the study used the test developed by H. Sievert. At the formative stage, the students of the experimental group, in addition to traditional training, participated in creativity training. The paper presents the results of diagnostics of indicators of the creative potential of future foreign language teachers as a result of the use of creativity training. The participants in the experimental training had an understanding of their capabilities, the development of the skills and abilities necessary for introducing creative activity in the future profession, the adaptation of new knowledge, skills, and abilities to their psychological characteristics (interiorization). The practical significance of the study lies in the introduction of creativity training into the system of training a future foreign language teacher at a university to improve the quality of the curriculum by influencing the psychological mechanisms of the professional and personal development of students.
\end{abstract}

Keywords: creativity, creativity training, edutainment, game technology.

\section{Introduction}

The transformations of public life dictate new requirements for the teacher's personality. Therefore, a strategic task of national importance is to increase the creative potential of future teachers.

\footnotetext{
*Corresponding author: galsors@ mail.ru
} 


\section{Literature review}

Research on the problems of creativity and creativity has a long history. Currently, the search for ways to develop the creative potential of teachers continues.

Effective methods of teacher training are modern active methods, such as the case study method, game methods like scrabble [1], the use of comics and content and language integrated learning (CLIL) [2], the project-based learning method, edutainment [3], etc.

For example, the new specialization of the teacher as game master involves mastering the technology of game modeling and methods of edutainment for training purposes. The educational and developmental features of games are well known and proven in science. Game technologies have firmly taken their place in the educational process, making this process more qualitative and meaningful because learning while playing has an active and personal nature, activates the mental activity of the student, stimulates them to achieve a specific goal.

Edutainment is gaining more and more popularity as a new form of learning that includes game technologies for the development of cognitive activity, passion, and maintaining attention throughout the lesson [2]. There is a large number of foreign studies that study the possibilities of edutainment technology in the training and personal development of students. Thus, H.M. Zin and N.Z. Zain study its influence on the effectiveness of education, considering this technology as an alternative to traditional educational technologies [4].

D. Buckingham and M. Scanlon view edutainment as a hybrid technology that depends on visual material, game formats and uses a more informal than the didactic style of communication [5].

In Russian pedagogical science, edutainment is viewed as a method that combines the content of educational material and creative teaching methods, which contributes to the emergence of students' desire to learn [6].

Psychological training plays a special role in improving the effectiveness of teachers' work. Training sessions have demonstrated a long-established and proven effectiveness in developing communication skills [7], in preventing teachers' emotional burnout and optimizing their psychological and emotional state [8], in the psychological correction of students' anxiety [9], etc.

We think that one of the most significant moments from the point of view of improving the effectiveness of teachers' work is the creativity training since the creative potential of both teachers and students can be expressed in a short time.

\section{Materials and methods}

To prove the effective influence of creativity training on the development of the creative potential of future teachers, we performed a study at the 1Linguistics University of Nizhny Novgorod in 2019. The study involved 180 students of the 1st and 2nd years of the Faculty of English enrolled in the Pedagogical education program: 90 people made up the control group (CG), and 90 people made up the experimental group (EG).

To diagnose the creative potential in the EG and CG at the ascertaining and control stages of the study, we used H. Sievert's test designed to determine the creative abilities of a person [9].

At the formative stage, the CG participants studied with the use of traditional teaching methods, such as lectures and seminars.

At the formative stage of the research with the EG participants, in addition to traditional teaching methods, we conducted several psychological training sessions aimed at developing the creative potential of the individual (development of creativity) using information blocks, psycho-gymnastic exercises, role-playing games, individual methods of stimulating the 
creative process (cause-effect diagram or Kaoru Ishikawa diagram (Fishbone diagram), the contradiction method, the random impulse method, the Leonardo da Vinci method, the Chinese strategy method, brain gymnastics, H. Aliyev's method, etc.) and group methods of stimulating the creative process (method of creating an idea by Tom Wujec, the method of situational analysis, the method of brainstorming, the method of right hemisphere drawing, etc.) $[10]$.

The purpose of the training sessions is to develop the creative potential of future teacherlinguists and the use of creative strategies in the educational process.

The objectives of the training sessions were aimed at understanding what creativity was, the difference between creativity as a personal potential and the creative process; definition of professional situations where the teacher needed creativity; realizing the external and internal barriers to the manifestation of creativity; understanding the stages of the creative process, studying individual and group methods of stimulating the creative process; creation of a creative environment and the formation of skills in managing the creative process of students.

Practical tasks at creativity training sessions were aimed at harmonizing the work of the right and left hemispheres of the brain for processing information by both hemispheres of the brain, at developing the ability to generate non-standard solutions and ways of behaving in professional and personal situations, at mastering creative technologies and strategies.

\section{Results}

Table 1 shows the results of diagnostics of the creative potential indicators of future teacherlinguists at the EG and CG before and after the creativity training sessions.

Table 1. Results of diagnostics of indicators of the creative potential of future teachers at the EG and $\mathrm{CG}$ at the summative and control stages of the study $(\mathrm{EG}=100, \mathrm{CG}=40, \mathrm{~N}=140$, average level indicators (ALI), $\Phi, \mathrm{p})$.

\begin{tabular}{|l|c|c|c|c|}
\hline \multirow{2}{*}{$\begin{array}{c}\text { Indicators of creative } \\
\text { potential }\end{array}$} & \multicolumn{2}{|c|}{ EG ALI } & \multicolumn{2}{c|}{ CG ALI } \\
\cline { 2 - 5 } & Summative & Control & Summative & Control \\
\hline Inventiveness (I) & 1.10 & 1.60 & 1.10 & 1.10 \\
\hline Ability to combine (C) & 1.40 & $2.10^{*}$ & 1.40 & 1.40 \\
\hline Divergent thinking (D) & 1.70 & $2,20^{*}$ & 1.70 & 1.70 \\
\hline Visual creativity (V) & 1.70 & $2.60^{*}$ & 1.70 & 1.70 \\
\hline Freedom of Association (FA) & 1.50 & $2.50^{*}$ & 1.50 & 1.50 \\
\hline \multicolumn{4}{|l|}{ Significance of differences by Fischer's criterion $\Phi^{*}: *-\mathrm{p} \leq 0.05, * * \mathrm{p} \leq 0.01$} \\
\hline
\end{tabular}

Note: The results are presented in the form of $A L I$.

The summative stage of the study showed that the results of the control (CG) and experimental (EG) samples did not differ from each other.

A comparative analysis of the results of the EC and the CG at the summative and control stages of the study showed that the indicators of the creative potential of the CG had remained unchanged. This allowed us to conclude that the traditional methods of teaching such as lectures and seminars were ineffective for the development of the creative potential of the personality of future teacher-linguists.

The students of the EG had significant positive changes in the indicators of creative potential on all scales, namely, the ability to combine, divergent thinking (fluency, flexibility, originality, curiosity, the ability to improve the object by adding details, etc.), visual creativity and freedom of association. 


\section{Discussion}

During the training, participants had an understanding of their capabilities and limitations in interacting with students, mastering the skills necessary for the development of students' creative potential, appropriating and adapting new knowledge, skills and abilities to their psychological characteristics (interiorization), active and conscious use of skills and abilities in the professional sphere (generalization), developing the ability to choose skills and skills that were appropriate for professional communication situations and individual psychological characteristics of students (relevance). Smaller changes had occurred on the inventiveness scale, which requires further research and more detailed analysis.

The results of the study suggest that training forms of work, in comparison with traditional teaching methods, are more effective for the development of the creative potential of the personality of future teachers. It is the training forms of work that should be used to develop the creative potential of students of pedagogical universities for the professional and creative formation and mastering psychological competencies.

\section{Conclusion}

The conducted study allows us to state that the modern teacher faces fundamentally new tasks related to the development of the intellectual and creative potential of society through a positive influence on the formation of the personality of a Russian citizen in a comprehensive school. This makes the use of activity-based, active methods of teacher training at the university more relevant. An experimental study of the use of creativity training showed that with its help, a significant increase in the creative potential of the future teacher's personality is achieved in such important indicators for professional activity as divergent thinking (fluency, flexibility, originality, curiosity, the ability to improve the object by adding details, etc.), visual creativity, freedom of association, ability to combine. There is a qualitative transformation of the student's personality in the direction of the development of professional self-awareness (self-esteem in terms of their psychological characteristics, awareness of the importance of professional knowledge and skills, the ability to make an appropriate selection of professional actions in different situations). Thus, the results of the use of creativity training indicate an increase in the quality of training of the future teacher both in terms of acquiring professionally significant skills and in terms of forming professional consciousness.

The training developed and implemented by us for the development of creative potential (creativity) of future teacher-linguists showed high efficiency and confirmed the fundamental possibility of purposeful development of creative potential in the process of professional university training.

\section{References}

1. E.J. Okulicz, The journey from novice to expert in competitive Scrabble players: An investigation of the development of expertise in a community of practice, Doctor of Philosophy thesis (The University of Wollongong, Dubai, 2010). Accessed on: January 25, 2020. [Online]. Available: http://ro.uow.edu.au/cgi/viewcontent.cgi/free

2. L.C. Ravelo, Latin American Journal of Content and Language Integrated Learning, 6(1), 1-19 (2013). https://doi.org/10.5294/laclil.2013.6.1.1

3. T. Pasawano, Procedia - Social and Behavioral Sciences, 176, 946-951 (2015) 
4. H.M. Zin, N.Z. Zain, The effects of edutainment towards students' achievements, in Proceedings of Regional Conference on Knowledge Integration in ICT, 129, 64-72 (2010)

5. R. White, That's Edutainment (White Hutchinson Leisure \& Learning Group, Kansas City, 2014). Accessed on: February 25, 2020. [Online]. Available: http://www.whitehutchinson.com/leisure/articles/edutainment.shtml

6. O.M. Zheleznyakova, O.O. Dyakonova, Nauchnyi Zhurnal Alma Mater, 2, 67-70 (2018)

7. G.V. Sorokoumova, Gumanizatsiya Obrazovaniya, 3, 46-51 (2018)

8. G.V.Sorokoumova, Gumanizatsiya Obrazovaniya, 3, 123-130 (2019)

9. H. Sievert, Test na opredeleniye tvorcheskikh sposobnostey [Test for the determination of creative abilities], in Testirovaniye lichnosti [Personality testing] (Interekspert, Moscow, 2019). Accessed on: January 09, 2020. [Online]. Available: https://nsportal.ru/shkola/klassnoe-rukovodstvo/library/2019/04/07/test-naopredelenie-tvorcheskih-sposobnostey-h

10. G.V. Sorokoumova, Psikhologiya tvorchestva i kreativnosti: uchebnoe posobie po kursu 'Psikhologiya tvorchestva' [Psychology of creativity and creativity: a textbook for the 'Psychology of Creativity' course] (URAO NF, Nizhnii Novgorod, 2017)

11. O.G. Milashina, Sotsialno-psikhologicheskii trening kak sredstvo korrektsii trevozhnosti studentov vuza [Socio-psychological training as a means of correcting anxiety among university students], Author's abstract of a Candidate of Psychological Sciences dissertation (Novosibirsk State Pedagogical University, Novosibirsk, 2010) 